STUDIES IN GREEK PHILOSOPHY

VOLUME II: SOCRATES, PLATO,

AND THEIR TRADITION 


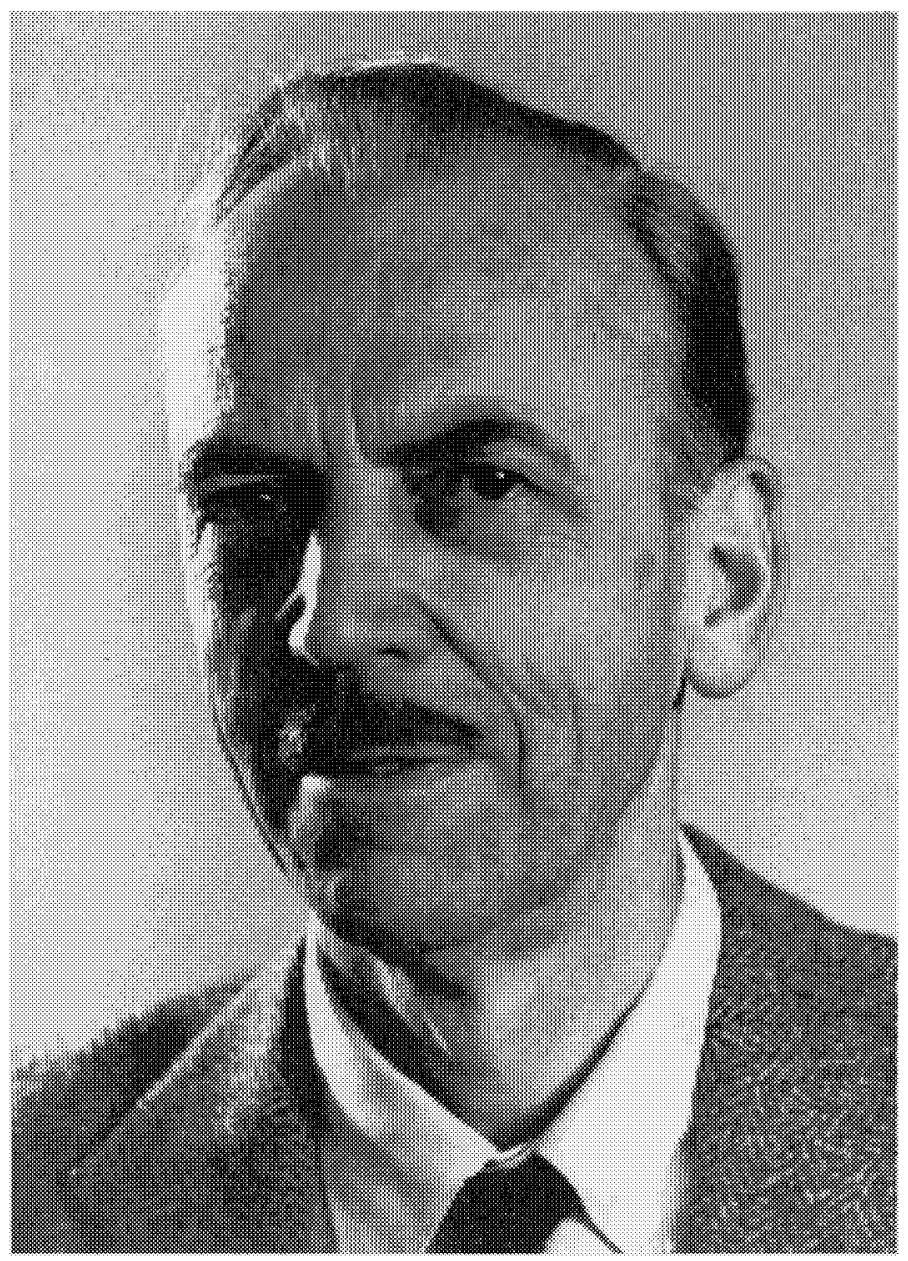

\section{Gregory Vlastos}




\section{STUDIES IN GREEK PHILOSOPHY}

\section{GREGORY VLASTOS}

VOLUME II: SOCRATES, PLATO,

AND THEIR TRADITION

Edited by Daniel W. Graham

PRINCETON UNIVERSITY PRESS

PRINCETON, NEW JERSEY 
Copyright $(1995$ by Princeton University Press

Published by Princeton University Press, 41 William Street,

Princeton, New Jersey 08540

In the United Kingdom: Princeton University Press, Chichester,

West Sussex

All Rights Reserved

\section{Library of Congress Cataloging-in-Publication Data}

Vlastos, Gregory

Studies in Greek philosophy / Gregory Vlastos.

p. $\mathrm{cm}$.

Includes bibliographical references and indexes.

Contents: v.1. The Presocratics - v.2. Socrates, Plato, and their tradition.

ISBN 0-691-03311-0

ISBN 0-691-01938-X (pbk.)

1. Philosophy, Ancient. I. Graham, Daniel W. II. Title.

B171.V538 $1994 \quad 180-\mathrm{dc} 20 \quad 94-3112$

This book has been composed in Times Roman

Princeton University Press books are printed on acid-free paper and meet the guidelines for permanence and durability of the Committee on Production Guidelines for Book Longevity of the Council on Library Resources

Printed in the United States of America 